\title{
TERAPI MUSIK TRADISIONAL KECAPI SULING SUNDA MENGATASI TINGKAT NYERI IBU POST OPERASI SECTIO CAESAREA
}

\author{
${ }^{1}$ Linda Sepriliani, ${ }^{2}$ Nunung Mulyani, $\&{ }^{3}$ Helmi Diana \\ ${ }^{1}$ Alumni Poltekkes Kemenkes Tasikmalaya \\ ${ }^{2,3}$ Dosen Poltekkes Kemenkes Tasikmalaya
}

\begin{abstract}
Abstrak
Tujuan penelitian adalah untuk mengetahui pengaruh terapi musik tradisional kecapi suling Sunda terhadap penurunan tingkat nyeri ibu post operasi sectio caesarea. Metode penelitian yang digunakan adalah eksperimen dengan jenis penelitian quasi eksperimen, dengan pendekatan pretest-posttest without control group. Populasi dalam penelitian ini adalah seluruh ibu post sectio caesarea yang dirawat RSUD dr.Soekardjo Tasikmalaya periode bulan Desember 2016 - Februari 2017 sebanyak 112 orang. Teknik pengambilan sampel menggunakan teknik accidental sampling yaitu sebanyak 50 orang. Hasil penelitian menunjukkan bahwa nyeri post operasi pada ibu dengan sectio caesarea sebelum dilakukan terapi musik tradisional ada pada kategori nyeri sedang yaitu sebanyak 32 orang (64,0\%). Nyeri post operasi setelah dilakukan terapi musik tradisional ada pada kategori ringan yaitu sebanyak 36 orang $(72,0 \%)$. Hasil uji wilcoxon signed rank test, dengan $p$ value (Asymp. Sig 2 tailed) sebesar 0,000 di mana kurang dari batas kritis penelitian 0,05 , maka Ho ditolak yang artinya bahwa ada pengaruh terapi musik tradisional kecapi suling Sunda terhadap nyeri ibu post operasi sectio caesarea di RSUD dr. Soekardjo Kota Tasikmalaya. Hasil penelitian ini merekomendasikan terapi musik tradisional kecapi suling Sunda sebagai intervensi nonfarmakologi untuk mengurangi nyeri pada ibu post operasi sectio caesarea.
\end{abstract}

Kata Kunci: Musik tradisional, kecapi suling, nyeri, sectio caesarea

\begin{abstract}
Abstrac
This study aimed at knowing the influence of Sundanese flute and lute traditional music therapy on the decrease of post-sectio caesarea women's pain level. The study used quasiexperimental research with the pretest-posttest without control group design. The population was all women of post-sectio caesarea treated in the Hospital of dr.Soekardjo Tasikmalaya in December 2016 - February 2017 as many people 112. The sample size was 50 women selected by using accidental sampling. The research result showed that before getting traditional music therapy, 32 women $(64,0 \%)$ had medium pain. After getting traditional music therapy, 36 women (72,0\%) had low pain. The result of wilcoxon signed rank test showed with the $\rho$ value (Asymp. Sig 2 tailed) 0.000, and it was smaller than the critical value (0.05). Therefore, $H_{0}$ was rejected. It means, there was influence of Sundanese flute and lute traditional music therapy on the decrease of post-sectio caesarea women's pain level in the Hospital of dr. SoekardjoTasikmalaya.The results of this study recommend the therapy of traditional Sundanese music as a non-pharmacological intervention to reduce pain in postoperative mother sectio caesarea.
\end{abstract}

Keywords: traditional music, flute and lute, pain, sectio caesarea

\section{PENDAHULUAN}

Persalinan dengan sectio caesarea memiliki resiko tinggi karena dilakukan pembedahan dengan membuka dinding perut dan dinding uterus atau insisi transabdominal uterus, pasien post operasi sectio caesarea akan merasakan nyeri.
Rasa nyeri merupakan stresor yang dapat menimbulkan stres dan ketegangan dimana individu dapat berespon secara biologis dan perilaku yang menimbulkan respon fisik dan psikis. Respon fisik meliputi perubahan keadaan umum, wajah, denyut nadi, pernafasan, suhu badan, sikap badan, dan 
apabila nafas semakin berat dapat menyebabkan kolaps kardiovaskuler dan syok, sedangkan respon psikis akibat nyeri dapat merangsang respon stres yang dapat mengurangi sistem imun dalam peradangan, serta menghambat penyembuhan, respon yang lebih parah akan mengarah pada ancaman merusak diri sendiri (Corwin, 2006).

Menurut World Health Organization (WHO), standar rata-rata Sectio Caesarea di sebuah negara sekitar 5-15\% per 1000 kelahiran di dunia. Di Asia Tenggara jumlah persalinan dengan Sectio Caesarea sebanyak 9550 kasus per 100.000 kasus pada tahun 2005. (Bernatzky 2011). Di Indonesia angka kejadian Sectio Caesarea tahun 2009 telah mencapai 29,6\%, yang berarti sudah melewati batas rata-rata yang ditentukan oleh WHO (Afriani A, 2013).

Berdasarkan data dari rekam medik RSUD dr.Soekardjo Tasikmalaya pada tahun 2015 didapatkan persalinan dengan tindakan operasi sectio caesarea sebanyak 574 jiwa dan persalinan pervaginam sebanyak 1833 jiwa, sedangkan pada periode Januari-Agustus 2016 didapatkan data persalinan dengan tindakan sectio caesarea sebanyak 716 jiwa dan persalinan pervaginam sebanyak 1277 jiwa (Rekam medik RSUD dr.Soekardjo, 2016).

Manajemen nyeri dengan terapi nonfarmakologi merupakan tindakan menurunkan nyeri tanpa menggunakan agen farmakologi atau mengkombinasikan agen farmakologi dan nonfarmakologi. Terapi nonfarmakologi untuk mengurangi nyeri post operasi salah satunya adalah dengan menggunakan terapi musik (Andarmoyo, 2013)

Berdasarkan hasil studi pendahuluan pada tanggal 7 September 2016 di RSUD dr.Soekardjo Tasikmalaya setelah dilakukan wawancara dengan bidan di ruang 1 , penanganan nyeri pada pasien post operasi sectio caesarea diberikan analgetik sesuai advis dokter, untuk menangani nyeri post operasi sectio caesarea biasanya diberikan terapi analgetik ketorolac dalam cairan Ringer Laktat atau cairan futrolit selama 24 jam. Pasien di pindahkan ke ruang 1 sesudah beberapa jam operasi dan pasien biasanya sudah sadar. Operasi sectio caesarea di RSUD dr.Soekardjo kebanyakan menggunakan anastesi lumbal dengan pengaruh anastesi akan hilang 8-12 jam sehingga dalam waktu tersebut pasien akan mengeluh nyeri pada daerah luka.

Penatalaksanaan dalam melakukan manajemen nyeri post operasi sectio caesarea di Ruang 1 kebidanan belum pernah melakukan intervensi nonfarmakologis seperti melakukan terapi musik, sampai saat ini pasien hanya dianjurkan untuk menarik nafas dalam jika merasa nyeri, dengan alasan, nyeri yang dirasakan ibu post operasi sectio caesarea itu merupakan nyeri yang wajar dan bersifat subjektif dan akan berkurang dengan pemberian analgetik. Selain melakukan wawancara dengan bidan yang bertugas di ruangan, dilakukan juga tes pengukuran skala nyeri terhadap 7 ibu post operasi sectio caesarea pada saat setelah 8 jam post operasi. Dari 7 ibu post operasi sectio caesarea terdapat 4 orang $(57,14 \%)$ ibu yang mengeluh nyeri berat, dan 3 orang $(42,85 \%)$ ibu lainnya mengeluh nyeri sedang.

Berdasarkan permasalahan di atas, maka peneliti tertarik untuk melakukan penelitian tentang "Pengaruh Terapi Musik Tradisional Kecapi Suling Sunda Terhadap Penurunan Tingkat Nyeri lbu post operasi sectio caesarea di RSUD dr.Soekardjo Tasikmalaya".

\section{METODE PENELITIAN}

Desain penelitian adalah penelitian quasi eksperimen dengan pendekatan pretest postest without control group, dimana pengambilan data dari kelompok yang sama.

Pengambilan sampel dengan cara purposive sampling. Ukuran sampel adalah sampel populasi sebanyak 50 orang, dengan responden yang memenuhi kriteria penelitian (inklusi). Kriteria inklusi; ibu post operasi sectio caesarea $>24$ jam, ibu post operasi sectio caesarea yang sudah tidak 
diberikan terapi analgetik, ibu post operasi sectio caesarea yang bersedia menjadi responden.

Instrumen penelitian menggunakan instrumen skala nyeri NRS, MP3, dan Earphone. Instrumen ini tidak perlu diuji lagi, karena sudah teruji validitasnya.

Setelah mendapat penjelasan, responden mengisi lembar persetujuan menjadi peserta penelitian kemudian dilanjutkan mengisi skala NRS sebelum dilakukan intervensi, kemudian melakukan intervensi terapi musik selama 15 menit, setelah dilakukan intervensi kemudian dilakukan pengisian skala nyeri NRS. Data yang dikumpulkan adalah data yang didapatkan melaluipenilaian terhadap hasil pengisian skala nyeri NRS. Data dikumpulkan langsung oleh tim peneliti. Data diedit dari kesalahan pengisian, kemudian diberikan kode untuk dianalisa, lalu ditransfer ke pengolahan komputer dan hasilnya ditampilkan dalam bentuk tabel.Setelah diketahui distribusi frekuensi data masing-masing variabel, selanjutnya dilakukan analisis bivariat dengan uji statistik wilcoxon signed rank test.

\section{HASIL PENELITIAN}

Tabel 1. Distribusi Frekuensi Tingkat Nyeri Ibu Post Operasi Sectio Caesarea Sebelum Terapi Musik Tradisional Kecapi Suling Sunda

\begin{tabular}{ccc}
\hline Tingkat Nyeri & Frekuensi & Persentase \\
\hline Nyeri ringan & 3 & 6,0 \\
\hline Nyeri sedang & 32 & 64,0 \\
\hline Nyeri berat & 15 & 30,0 \\
\hline Jumlah & $\mathbf{5 0}$ & $\mathbf{1 0 0}$
\end{tabular}

Berdasarkan Tabel 1. Menunjukkan bahwa tingkat nyeri ibu post operasi sectio caesarea sebelum dilakukan terapi musik tradisional kecapi suling Sunda di RSUD dr.Soekardjo Kota Tasikmalaya sebagian besar ada pada kategori Nyeri sedang yaitu sebanyak 32 orang $(64,0 \%)$, sedangkan sebagian kecil ada pada kategori Nyeri ringan yaitu sebanyak 3 orang $(6,0 \%)$.

Tabel 2. Distribusi Frekuensi Tingkat Nyeri Ibu Post Operasi Sectio Caesarea Sesudah Terapi Musik Tradisional Kecapi Suling Sunda

\begin{tabular}{ccc}
\hline Tingkat Nyeri & Frekuensi & Persentase \\
\hline Nyeri ringan & 36 & 72,0 \\
\hline Nyeri sedang & 14 & 28,0 \\
\hline Jumlah & $\mathbf{5 0}$ & $\mathbf{1 0 0}$ \\
\hline
\end{tabular}

Berdasarkan Tabel 2 menunjukkan bahwa tingkat nyeri ibu post operasiSectio Caesarea sesudah dilakukan terapi musik tradisional kecapi suling Sunda di RSUD dr.Soekardjo Kota Tasikmalaya ringan yaitu sebanyak 36 orang $(72,0 \%)$, sedangkan sebanyak 14 orang $(28,0 \%)$ ada pada kategori nyeri sedang.

Tabel 3. Pengaruh Terapi Musik Tradisional Kecapi Suling Sunda Terhadap Penurunan Tingkat Nyeri lbu Post Operasi Sectio Caesarea

\begin{tabular}{ccccc}
\hline N & $\begin{array}{c}\text { Mean } \\
\text { Rank }\end{array}$ & $\begin{array}{c}\text { Sum } \\
\text { Rank }\end{array}$ & Nilai Z & Sig \\
\hline 50 & 25,50 & 1275 & $-6,213$ & 0,000
\end{tabular}

Berdasarkan hasil dari perhitungan wilcoxon signed rank test, maka nilai $Z$ yang didapat sebesar -6,213 dengan $p$ value (Asymp. Sig 2 tailed) sebesar 0,000 di mana kurang dari batas kritis penelitian 0,05, maka Ho ditolak yang artinya bahwa ada pengaruh terapi musik tradisional kecapi suling Sunda terhadap nyeri ibu post operasi sectio caesarea di RSUD dr.Soekardjo Kota Tasikmalaya.

\section{PEMBAHASAN}

Berdasarkan hasil penelitian menunjukkan bahwa nyeri sebelum diberikan terapi musik tradisional kecapi suling Sunda selama perawatan post operasi sectio caesarea di RSUD dr. Soekardjo Kota Tasikmalaya sebagian 
besar ada pada kategori nyeri sedang sebanyak 32 orang $(64,0 \%)$, dan kategori nyeri berat sebanyak 15 orang $(30,0 \%)$. Hasil penelitian ini didukung dari penelitian Oktavia, Gandamiharja dan Akbar (2013) dengan hasil bahwa sebelum dilakukan terapi musik klasik mozart dan musik gamelan mayoritas nyeri yang dialami responden adalah nyeri berat $45 \%$.

Sectio caesarea merupakan kelahiran janin melalui insisi di dinding abdomen (laparotomi) dan dinding uterus (histerotomi), definisi ini tidak mencakup pengeluaran janin dari rongga abdomen pada kasus ruptur uterus atau pada kasus kehamilan abdomen (Williams, 2013).

Komplikasi yang dapat terjadi pada ibu post operasi sectio caesarea adalah infeksi dan nyeri yang di dapat di rumah sakit terutama setelah dilakukan seksio pada persalinan (Gerhard martius, 2012).

Tingkat nyeri yang dirasakan responden dipengaruhi oleh beberapa faktor. Menurut Aziz (2009) menyatakan bahwa beberapa faktor yang mempengaruhi nyeri antara lain usia, jenis kelamin, latar belakang sosial budaya, lingkungan, pengalaman, persepsi nyeri, toleransi nyeri, dan reaksi terhadap nyeri.

Tingkat nyeri sesudah diberikan terapi musik tradisional kecapi suling Sunda sebagian besar ada pada kategori nyeri ringan sebanyak 36 orang $(72,0 \%)$ dan kategori nyeri sedang sebanyak 14 orang (28,0\%).

Hasil penelitian lain yang dilalukan McCaffrey yang menemukan bahwa intensitas nyeri menurun sebanyak 33\% sesudah terapi musik dengan musik klasik Mozart selama 20 menit terhadap pasien osteoarthritis (Novita, 2012).

Hal ini sesuai dengan pernyataan Mitchell dan MacDonald (2008) yang mengemukakan efek terapi musik terhadap nyeri adalah distraksi terhadap pikiran tentang nyeri, menurunkan kecemasan, menstimulasi ritme nafas lebih teratur, menurunkan ketegangan tubuh, memberikan gambaran positif terhadap visual imagery, relaksasi, meningkatkan mood yang positif. Terapi musik dengan pendekatannya yang unik dan universal dapat membantu mencapai tujuan dengan penurunan stress, ketakutan akan penyakit dan cedera, menurunkan tingkat depresi, kecemasan, insomnia. Terapi musik juga mendorong perilaku kesehatan yang positif, mendorong kemajuan kesembuhan pasien selama masa pemulihan dan pengobatan (Novita, 2012).

Dr. John Diamond dan Dr. David Nobel, telah melakukan riset mengenai efek dari musik terhadap tubuh manusia dimana mereka menyimpulkan bahwa jenis musik yang yang kita dengan sesuai dan dapat diterima oleh tubuh manusia, maka tubuh akan bereaksi dengan mengeluarkan sejenis hormon (serotonin) yang dapat menimbulkan rasa nikmat dan senang sehingga tubuh akan menjadi lebih kuat (dengan meningkatnya sistem kekebalan tubuh) dan membuat kita menjadi lebih sehat (Eka, 2009).

Penurunan tingkat nyeri sesudah diberikan terapi musik pada pasien post operasi sectio caesarea terjadi karena hormon endorfin yang telah distimulus setelah post operasi sectio caesarea yang memiliki efek mengurangi nyeri. Hal ini didukung oleh Chiang 2012 dalam Novita (2012) bahwa musik yang bersifat sedatif terbukti efektif dalam mengurangi nyeri.

Schou (2008), Nilsson (2009), dan Chiang (2012) mengemukakan tentang jenis musik yang direkomendasikan untuk terapi musik yaitu Instrumentaslis musik klasik, slow jazz, pop, folk, wetern coutry, easy listening, dan musik tradisional.

Hasil penelitian menunjukkan ada pengaruh terapi musik trasidional kecapi suling Sunda terhadap penurunan tingkat nyeri pada pasien post operasi sectio caesarea di RSUD dr.Soekardjo dengan $p$ value (Asymp. Sig 2 tailed) sebesar 0,000 di mana kurang dari batas kritis penelitian 0,05 .

Hasil penelitian Alifa Safitri 2012, dari Universitas Muhammadiyah Yogyakarta mengemukakan bahwa ada pengaruh terapi musik tradisional langgam Jawa terhadap 
penurunan rasa nyeri yang dirasakan ibu bersalin. Hasil penelitian ini diperkuat oleh hasil penelitian dari Oktavia, Gandamiharja dan Akbar (2013) dengan hasil bahwa didapatkan perbedaan yang bermakna antara nyeri sebelum dan sesudah dilakukan terapi musik.

Menurut Potter \& Perry (2006) salah satu upaya mengatasi rasa nyeri dengan memberikan terapi nonfarmakologi yang merupakan tindakan menurunkan nyeri tanpa menggunakan agen farmakologi. Ada beberapa penanganan berdasarkan penatalaksanaan nyeri nonfarmakologi yaitu dengan stimulasi fisik yang meliputi bimbingan antisipasi, terapi es, kompres panas dan dingin, relaksasi, imajinasi terbimbing, hipnosis, akupuntur, umpan balik biologis massage stimulasi saraf elektris transkutan (TENS), distraksi (distraksi visual, audio atau terapi musik, distraksi intelektual) (Andarmoyo, 2013).

Distraksi adalah memfokuskan perhatian pasien pada sesuatu selain nyeri, atau dapat diartikan dengan lain bahwa distraksi adalah suatu proses pengalihan perhatian pasien selain diluar rasa nyeri (Andarmoyo, 2013)

Musik menghasilkan perubahan status kesadaran melalui bunyi, kesunyian, ruang, dan waktu. Musik harus didengarkan minimal 15 menit agar dapat memberikan efek teraupeutik. Dikeadaan perawatan akut, mendengarkan musik dapat memberikan hasil yang sangat efektif dalam upaya mengurangi nyeri pasca operasi pasien (Potter \& Perry, 2006).

Musik bekerja pada sistem saraf otonom yaitu bagian sistem saraf yang bertanggung jawab mengontrol tekanan darah, denyut nadi, denyut jantung, fungsi otak, yang mengontrol perasaan dan emosi. Menurut penelitian, kedua sistem tersebut bereaksi sensitif terhadap musik. Saat merasa sakit, kita menjadi takut, frustasi dan marah yang membuat kita menegangkan otot-otot tubuh, hasilnya rasa sakit menjadi semakin parah. Mendengarkan musik secara teratur membantu tubuh rileks secara fisik dan mental, sehingga membantu menyembuhkan dan mencegah rasa sakit. Pada proses persalinan dan setelah persalinan, terapi musik berfungsi mengatasi kecemasan dan mengurangi rasa sakit (Marmi, 2013).

Menurut Nilsson 2009 dalam Dian Novita (2012) musik yang bersifat sedatif tidak hanya efek distraksi dalam inhibisi persepsi nyeri. Musik dipercaya dapat meningkatkan pengeluaran hormon endorfin.

Endorfin merupakan ejektor dari rasa rileks dan ketenangan yang timbul, midbrain mengeluarkan Gama Amino Butyric Acid (GABA) yang berfungsi menghambat hantaran impuls listrik dari satu neuron ke neuron lainnya oleh neurotransmiter dalam sinaps. Midbrain mengeluarkan enkepalin dan beta endorfin kemudian zat tersebut dapat menimbulkan efek analgesik yang akhirnya mengeliminasi neurotransmiter rasa nyeri pada pusat persepsi dan interpretasi sensorik somatic di otak sehingga efek yang bisa muncul adalah nyeri berkurang (Guyton \& Hall, 2008).

Musik daerah atau musik tradisional adalah musik yang lahir dan berkembang di daerahdaerah di seluruh Indonesia. Ciri khas pada jenis musik ini terletak pada isi lagu dan instrumen (alat musiknya). Musik tradisional memiliki karakteristik khas, yakni syair dan melodinya menggunakan bahasa dan gaya daerah setempat. Contohnya musik tradisional dari sunda yang memiliki unsur terapi adalah musik kecapi suling. Kecapi adalah alat musik petik yang berasal dari daerah Jawa Barat. Suling adalah instrumen musik tiup yang terbuat dari bambu yang merupakan alat musik tradisional daerah Sunda. Kecapi suling merupakan perangkat waditra Sunda yang terdapat hampir disetiap daerah tataran Sunda, selain dapat disajikan untuk mengiringi juru sekar yang melantunkan lagu secara anggana sekar, instrumen kecapi suling Sunda juga dapat dilantunkan secara instrumental, sehingga musik tradisional ini akan terasa mempesona dan membuat nyaman jika keduanya dapatdimainkan secara bersamaan dan dapat menciptakan 
ketenangan membuat seseorang dapat berkomunikasi baik dengan hati maupun pikiran, dan memungkinkan dapat mengurangi rasa sakit yang dialami seseorang (Deherba.com).

\section{KESIMPULAN}

Tingkat nyeri ibu post operasi sectio caesarea sebelum intervensi terapi musik tradisional kecapi suling Sunda ada pada kategori nyeri sedang $(64,0 \%)$, dan sesudah diberikan intervensi terapi musik tradisional kecapi suling Sunda ada pada kategori nyeri ringan $(72 \%)$. Terdapat pengaruh terapi musik tradisional kecapi suling Sunda terhadap penurunan nyeri post operasi sectio caesarea dengan $(p=0,000)$.

Hendaknya petugas kesehatan khususnya Bidan dapat meningkatkan keterampilan terapi musik, khususunya untuk mengintervensi respon nyeri ibu post operasi sectio caesarea.

\section{DAFTARPUSTAKA}

Afriani, (2013). Kasus Persalinan Dengan Bekas Sectio Caesarea Menurut Keadaan Waktu Masuk dibagian Obstetri dan Ginekologi RSUP Dr.M Djamil Padang Vol.3,No.2

Alimul, A., (2009). Keterampilan Dasar Praktik Klinik untuk Kebidanan. Jakarta : Salemba Medika
Andarmoyo, S.S., (2013). Nyeri Persalinan Tanpa Nyeri Berlebihan. Yogyakarta: Ar-Ruzz Media.

Corwin, J.E., (2006). Patofisiologi, Jakarta: EGC

Erwin, E., (2009). Pusat Riset Terapi Musik Dan Gelombang Otak Indonesia. Diakses tanggal 07 September 2016 dari www.http//terapimusik.com.

Martius, G., (2012). Bedah Kebidanan Martius. Jakarta: EGC

Oktavia, Gandamiharja, \& Akbar, (2013). Perbandingan Efek Musik Klasik Mozart dan Musik Tradisional Gamelan Jawa terhadap Pengurangan Nyeri Persalinan Kala 1 Fase Aktif pada Nulipara: Universitas Padjajaran. Vol.45, No.4.

Novita, D., (2012). Pengaruh Terapi Musik Terhadap Nyeri Post Operasi ORIF di RSYD Dr.H. Abdul Moeloek Provinsi Lampung, Nilsson u 2009 soothing music can increase oxytocin level during bed rest after open-heart surgery: A Randomised Control Trial, Jurnal Of Clinical Nursing, 18, 21532161.

Potter, \& Perry, (2006). Fundamental of Nursing. Jakarta : EGC

Williams, (2013). Obstetri Williams Panduan Ringkas. Jakarta : EGC. 